\title{
Effects of hydrogen sulfide on the feeding activity of Manila clam Ruditapes philippinarum
}

\author{
Sou Nagasoe ${ }^{1,2 *}$, Tatsuya Yurimoto ${ }^{1,3}$, Kengo Suzuki ${ }^{1}$, Yukio Maeno ${ }^{1,3}$, \\ Katsunori Kimoto ${ }^{1}$

\begin{abstract}
${ }^{1}$ Seikai National Fisheries Research Institute, Fisheries Research Agency, Nagasaki, Nagasaki 851-2213, Japan ${ }^{2}$ Miyazu Station, National Center for Stock Enhancement, Fisheries Research Agency, Miyazu, Kyoto 626-0052, Japan ${ }^{3}$ Japan International Research Center for Agricultural Sciences, Tsukuba, Ibaraki 305-8686, Japan
\end{abstract}

\begin{abstract}
After being exposed to anoxia for $24 \mathrm{~h}$, with and without hydrogen sulfide $\left(\mathrm{H}_{2} \mathrm{~S} ; 5\right.$ or $30 \mathrm{mg} \mathrm{l}^{-1}$ ), the feeding activities of the Manila clam Ruditapes philippinarum were examined in the laboratory under normoxic conditions. The clearance rates of clams after exposure to anoxia with $30 \mathrm{mg} \mathrm{l}^{-1} \mathrm{H}_{2} \mathrm{~S}\left(5.1 \mathrm{l} \mathrm{h}^{-1}\right.$ ind. $\left.^{-1}\right)$ were significantly lower than in those exposed to normoxic or anoxic conditions (11.4 or $11.2 \mathrm{l} \mathrm{h}^{-1}$ ind..$^{-1}$, respectively). The phytopigment concentration of the digestive glands of clams treated with $30 \mathrm{mg} \mathrm{l}^{-1} \mathrm{H}_{2} \mathrm{~S}$ under anoxic conditions $\left(41.7 \mathrm{\mu g} \mathrm{g}^{-1}\right.$, wet weight of digestive gland) was significantly lower than that measured in other experimental treatments in this study (548.4 $\mathrm{\mu g} \mathrm{g}^{-1}$ for normoxia, $461.9 \mathrm{\mu g} \mathrm{g}^{-1}$ for anoxia only, $479.8 \mathrm{\mu g} \mathrm{g}^{-1}$ for $5 \mathrm{mg} \mathrm{l}^{-1}$ sulfidic anoxia; $\mathrm{p}<0.01$ ). Histological examination of clam tissue revealed that the ciliary epithelium was damaged by a high concentration of $\mathrm{H}_{2} \mathrm{~S}$. These findings indicate that once the clams suffered damage to their gills by exposure to $\mathrm{H}_{2} \mathrm{~S}$, their feeding activity was impaired and they could not ingest prey, even when their environment was returned to optimal conditions.
\end{abstract}

KEY WORDS: Clearance rate $\cdot$ Gill $\cdot$ Digestive gland $\cdot$ Ingestion $\cdot$ Histology Resale or republication not permitted without written consent of the publisher

\section{INTRODUCTION}

Bottom water in eutrophic, closed, inner bays and neritic regions often becomes anoxic during the summer stratification period, due to oxygen consumption by organic material, that has either been discharged by human activity or produced naturally. Oxygen consumption in the bottom sediment, associated with organic decomposition, causes the seabed environment to shift from an oxidizing to a reducing condition. Under reducing conditions, hydrogen sulfide $\left(\mathrm{H}_{2} \mathrm{~S}\right)$ is often produced by sulfate reduction. $\mathrm{H}_{2} \mathrm{~S}$ is harmful to aerobic organisms because it inhibits the respiratory enzyme cytochrome $c$ oxidase (Smith et al. 1977). Therefore, the generation of $\mathrm{H}_{2} \mathrm{~S}$ in sediment or in the bottom layer of a water body has a strong negative effect on the survival of benthic infauna (Vismann 1991, Diaz \& Rosenberg 1995). In oxygen-saturated seawater, however, $\mathrm{H}_{2} \mathrm{~S}$ has a halflife of about $20 \mathrm{~min}$ (Ostlund \& Alexander 1963). Thus, there is not much effect of $\mathrm{H}_{2} \mathrm{~S}$ in oxygen saturated seawater.

The Manila clam Ruditapes philippinarum (Adams \& Reeve, 1850) dominates the intertidal and upper subtidal zones of sandy tidal flats or shallow coastal areas along the eastern coast of Asia, the western coast of North America, and the northern coast of the Mediterranean; it is an important fishery resource in these regions (Chew 1989). Anoxic conditions and $\mathrm{H}_{2} \mathrm{~S}$ occur sporadically in the habitats of this clam (Yatsuka 1953, Hagita 1985, Higano 2005). Several studies have examined the combined effects of anoxia and $\mathrm{H}_{2} \mathrm{~S}$ on the survival or metabolic rates of various bivalves (Hagita 1985, Shumway et al. 1993, Oeschger \& Pedersen 1994, Nakamura et al. 1997, Laudien et al. 2002, Le Moullac et al. 2008). Accord- 
ing to these reports, bivalves that were cultured under anoxic conditions with $\mathrm{H}_{2} \mathrm{~S}$ in the water for several consecutive days were much less likely to survive than those cultured under anoxic conditions without $\mathrm{H}_{2} \mathrm{~S}$. Within the biotope of intertidal bivalves, however, the anoxic sulfidic condition would not continue for several days, because the substratum is exposed to air, and oxygen penetrates into the sediment during every tidal cycle. Furthermore, some intertidal bivalves can tolerate $\mathrm{H}_{2} \mathrm{~S}$ to some extent by oxidizing this poisonous compound into nontoxic compounds, mainly thiosulfate (Jahn et al. 1997, Jahn \& Theede 1997, Laudien et al. 2002). Therefore, it is unlikely that $\mathrm{H}_{2} \mathrm{~S}$ would be a direct cause of mortality of Manila clams in their natural environment. VaquerSunyer \& Duarte (2010) suggested that the fact that intertidal bivalves may remain alive after exposure to anoxia or sulfide does not necessarily mean they will survive long-term, as they may have been compromised enough to die subsequently of other causes.

To date, no studies have examined the physiological sequelae or histological lesions of bivalves following exposure to $\mathrm{H}_{2} \mathrm{~S}$. The objectives of the present study were to investigate the effects of $\mathrm{H}_{2} \mathrm{~S}$ exposure on the feeding behavior of Manila clams and to examine whether the clams' gill tissue is damaged by $\mathrm{H}_{2} \mathrm{~S}$.

\section{MATERIALS AND METHODS}

\section{Pre-experimental farming condition}

The Manila clams used for the experiments had a shell length of $34.13 \pm 1.79 \mathrm{~mm}$ (mean $\pm \mathrm{SD}, \mathrm{n}=46)$ and were collected in Konagai-cho, Nagasaki, Japan $\left(32^{\circ} 55^{\prime} 00^{\prime \prime} \mathrm{N}, \quad 130^{\circ} 10^{\prime} 10^{\prime \prime} \mathrm{E}\right)$. The clams were farmed in an indoor tank at $23^{\circ} \mathrm{C}$ and a salinity of 33 . They were fed a mixture of the diatom Chaetoceros gracilis (Tasaki Institute for Marine Biological Research) and Shellfish Micron M1 (Nosan), a commercial feed. Prior to the experiment, in order to clean their gut contents, the clams were kept for $5 \mathrm{~d}$ in a breeding tank through which aerated, algae-free seawater $\left(23^{\circ} \mathrm{C}\right.$, salinity 33$)$ flowed.

\section{Experimental design}

To examine the impact of $\mathrm{H}_{2} \mathrm{~S}$ under anoxic conditions (sulfidic anoxia), the clams were exposed to 2 different $\mathrm{H}_{2} \mathrm{~S}$ concentrations. The higher concentration (30 $\mathrm{mg} \mathrm{l}^{-1}$ ) was established based on $\mathrm{H}_{2} \mathrm{~S}$ measurements by Sakai et al. (2004) in surface sediment pore water (maximum concentration $\sim 37 \mathrm{mg} \mathrm{l}^{-1}$ ) in Lake Nakaumi, Japan, where Manila clams live. The lower concentration (5 $\mathrm{mg} \mathrm{l}^{-1}$ ) was established based on the field investigation of Hagita (1985).

The experiment consisted of a series of 3 procedures, described below. The entire series was performed twice.

Procedure 1: Anoxic incubation with and without $\mathrm{H}_{2} \mathrm{~S}$

Clams were exposed to anoxic conditions for $24 \mathrm{~h}$, with and without $\mathrm{H}_{2} \mathrm{~S}$, using the equipment illustrated in Fig. 1. Five clams were placed into an airtight separable flask (As One), and the cover was held in place tightly with 3 clamps. The flask was filled with $1.5 \mathrm{l}$ nitrogen-bubbled oxygen-free filtered seawater $\left(23^{\circ} \mathrm{C}\right.$, salinity $33, \mathrm{pH}$ adjusted to 7.5$)$, and the upper half of the flask was sealed with a stopper; no air space was left in the separable flask. Dissolved oxygen (DO) of the seawater was monitored by an Oxi 340i DO sensor (WTW) during the period of nitrogen bubbling. DO concentration remained below $0.4 \mathrm{mg} \mathrm{l}^{-1}$.

For anoxic exposure experiments with $\mathrm{H}_{2} \mathrm{~S}$, clams were incubated as described above. To introduce $\mathrm{H}_{2} \mathrm{~S}$, a $\mathrm{Na}_{2} \mathrm{~S} \cdot 9 \mathrm{H}_{2} \mathrm{O}$ solution was prepared and then immediately added to the nitrogen-bubbled oxygenfree filtered seawater to a final concentration of either 5 or $30 \mathrm{mg} \mathrm{l}^{-1}$ (pH 7.5). To prepare this solution, crystals of $\mathrm{Na}_{2} \mathrm{~S} \cdot 9 \mathrm{H}_{2} \mathrm{O}$ were weighed into a $30 \mathrm{ml}$

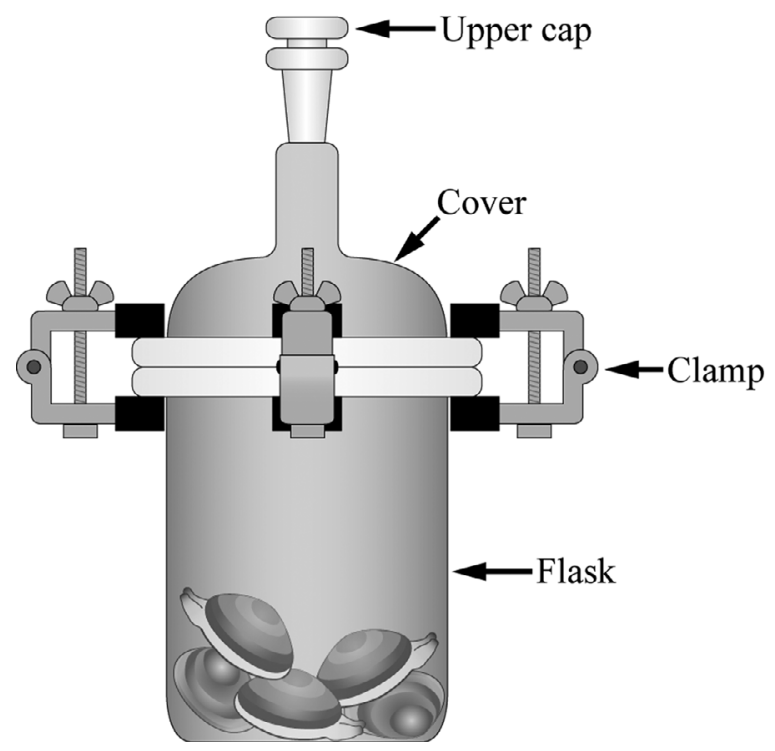

Fig. 1. Separable-flask exposure apparatus 
glass syringe (Tsubasa Industry), and 10 to $20 \mathrm{ml}$ of oxygen-free filtered seawater were slowly drawn into the syringe without aeration. $4 \mathrm{~N} \mathrm{HCl}$ was injected through an inlet of the syringe to adjust the $\mathrm{pH}$ of the water in the syringe to 7.5 . The $\mathrm{H}_{2} \mathrm{~S}$ solution was then injected into the seawater of each flask without aeration, the separable flask was filled with oxygen-free seawater to the maximum flask volume, and the upper cap was sealed. To confirm the concentration of $\mathrm{H}_{2} \mathrm{~S}$ in the separable flasks, we conducted a preliminary experiment to analyze the concentration using the methylene blue method (Cline 1969). In this paper, the term sulfide refers to all forms of $\mathrm{H}_{2} \mathrm{~S}$ $\left(\mathrm{H}_{2} \mathrm{~S}, \mathrm{HS}^{-}\right.$, and $\left.\mathrm{S}^{2-}\right)$.

As a control for the anoxic incubation with and without $\mathrm{H}_{2} \mathrm{~S}$, we also incubated clams under normoxic conditions using the same equipment (Fig. 1). Five Manila clams were incubated in a separable flask containing $1.5 \mathrm{l}$ of aerated filtered seawater $\left(23^{\circ} \mathrm{C}\right.$, salinity $33, \mathrm{pH}$ adjusted to 7.5$)$ without the upper cap in place. Additionally, the seawater in the flask was gently aerated to prevent a reduction in DO concentration.

Procedure 2: Measurement of clearance rate

In order to examine the effect of sulfide, the measurement of the clams' clearance rate was made under laboratory normoxic conditions according to the method outlined by Nagasoe et al. (2011). The clams used for this examination were the individuals that had been treated in Procedure 1. Six polypropylene beakers were prepared for each treated group (normoxic incubation, anoxic incubation without $\mathrm{H}_{2} \mathrm{~S}$, and anoxic incubation with 5 or $30 \mathrm{mg} \mathrm{l}^{-1} \mathrm{H}_{2} \mathrm{~S}$ ). Two liters of filtered seawater were added to each polypropylene beaker, and one clam each was placed into 5 beakers (hereinafter called 'assay beakers'). The sixth beaker ('control beaker') was left without a clam for the purpose of calculating a correction coefficient (see Eq. 1). The clams were stored under dim light at $23 \pm 1{ }^{\circ} \mathrm{C}$, and the temperature was maintained by an electrically heated water bath. After the clams were placed in the beakers, they were left undisturbed for $30 \mathrm{~min}$. A culture of the diatom Chaetoceros gracilis was added to all 6 beakers to a final concentration in each beaker of $\sim 2.5 \times 10^{4}$ cells $\mathrm{ml}^{-1}$ (prior to this inoculation, a volume of seawater equal to the algae culture's inoculum volume was drained from each beaker). The seawater in the beakers was gently aerated to ensure a homogeneous distribution of phytoplankton. The cell concen-

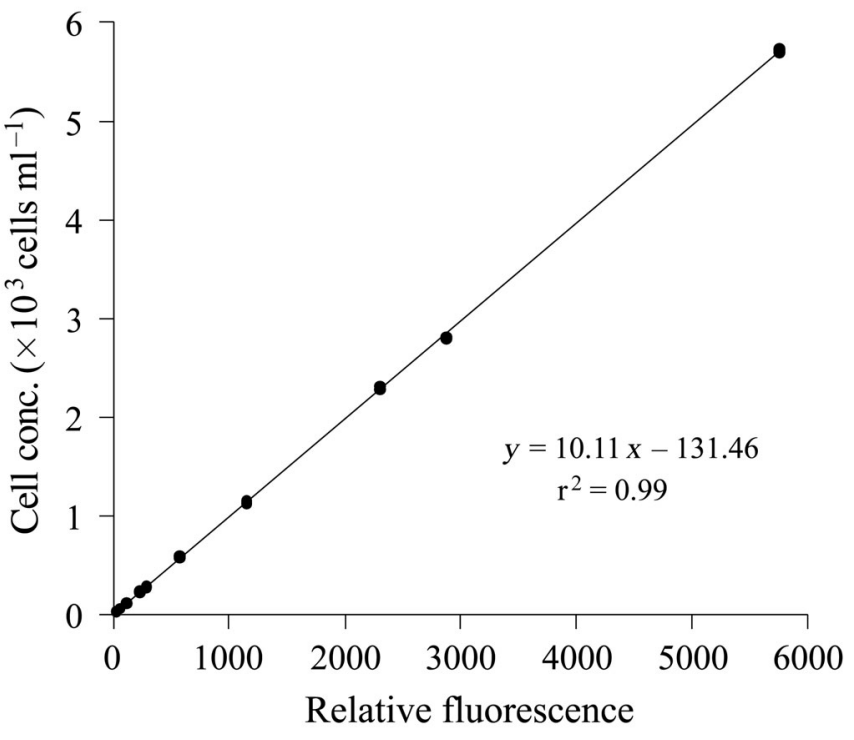

Fig. 2. Correlation between cell concentration and in vivo fluorescence of diatom Chaetoceros gracilis

tration of phytoplankton in each beaker was measured every hour for $4 \mathrm{~h}$.

The abundance of diatom cells was determined by measuring in vivo chl a fluorescence with a Model 8000-010 fluorometer (Turner Designs). Prior to the experiment's initiation, the correlation between cell concentration and in vivo fluorescence units of microalgae was examined (Fig. 2). Although the diatom concentration in the control beaker did not increase during these experiments (as confirmed by direct count under a light microscope), the in vivo chl a fluorescence per unit water volume increased slightly with time. This is a result of an increase in the in vivo chl a per cell (Fig. 3). We therefore calculated a correction coefficient to keep the in vivo chl a fluorescence of the control beaker constant:

$$
\text { Correction coefficient }=\frac{F_{0}}{F_{t}}
$$

where $F_{0}$ is the in vivo chl a fluorescence of the diatoms in the control beaker at the time of addition of inoculum and $F_{t}$ is the in vivo chl a fluorescence of the diatoms after $t$ hours. We corrected the cell concentration values of the assay beakers by multiplying them by this correction coefficient.

The rate of phytoplankton clearance by each clam $\left(C_{i} \mathrm{l} \mathrm{h}^{-1}\right.$ ind $\left.^{-1}\right)$ was calculated using the ln-transformed diatom cell concentration data for the $4 \mathrm{~h}$ measurement period according to the method of Coughlan (1969):

$$
C=\frac{V}{n \times t} \times \ln \frac{N_{0}}{N_{t}}
$$




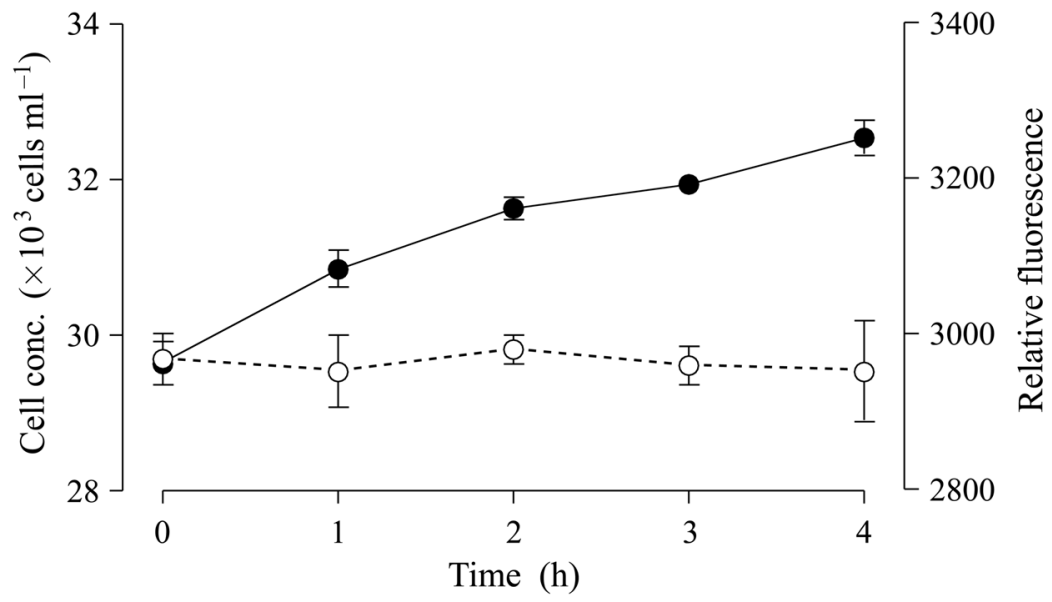

Fig. 3. Time-dependent changes in diatom cell concentration $(\mathrm{O}$, left axis) and in vivo chl a fluorescence per ml (•, right axis) in control beaker. Error bars indicate range of measured values

$4 \mathrm{~N} \mathrm{HCl}$ to the supernatant, $V(\mathrm{ml})$ is the volume of acetone used for the pigment extraction, $M(\mathrm{~g})$ is the wet weight of the digestive gland, and 1 $(\mathrm{cm})$ is the width of the quartz spectrophotometer cell.

We also examined whether anoxia, with or without $\mathrm{H}_{2} \mathrm{~S}$, caused damage to clam tissue. Three clams were randomly chosen from the 5 in each treatment 'assay beaker' (see Procedure 2) in one run (total 6 clams were used for each treatment group in 2 runs). One $5 \mathrm{~mm}$ cross-section was sampled from the middle region of the gill in each clam, fixed in a $10 \%$ mixture of formalin in seawater, and then dehydrated and embedded in paraffin. Three $5 \mu \mathrm{m}$ tissue sections obtained from different areas of each cross-section (one

where $N_{0}$ is the cell concentration (cells ml-1) at the time of addition of inoculum, $N_{t}$ is the cell concentration (cells $\mathrm{ml}^{-1}$ ) after $t$ hours, $V$ is the volume (l) of water in the beaker, and $n$ is the number of clams. In this experiment, the values of these variables were exactly $t=4, V=2$, and $n=1$.

Procedure 3: Analysis of phytopigment in digestive glands, and histological examination of tissue

After measuring clearance rate, the clams were immediately dissected and a piece of digestive gland (about $0.05 \mathrm{~g}$ ) was isolated from each clam. The analysis of phytopigments (chl $a+$ phaeophytin) in the digestive glands, carried out immediately after sample isolation, was performed according to the method of Numaguchi (2001). Each piece of wet digestive gland tissue was weighed, soaked in $10 \mathrm{ml}$ of $90 \%$ acetone in the dark at $4^{\circ} \mathrm{C}$ for $24 \mathrm{~h}$, and then centrifuged at $2300 \times g$ for $20 \mathrm{~min}$ to extract the pigment. After the addition of $50 \mu \mathrm{l}$ of $4 \mathrm{~N} \mathrm{HCl}, \sim 5 \mathrm{ml}$ of the supernatant was measured with a spectrophotometer at wavelengths of 665 and $750 \mathrm{~nm}$ to determine its phytopigment content. The phytopigment concentration $\left(\mu \mathrm{g} \mathrm{g}^{-1}\right)$ was determined using Eq. (3), which was modified from an equation developed by Strickland \& Parsons (1968):

$$
\text { Phytopigment conc. }=\frac{2.67 \times\left(1.7 E_{a}-E_{a}\right) \times v}{M \times 1}
$$

where $E_{a}$ is the absorbance difference between the values at 665 and $750 \mathrm{~nm}$ after the addition of $50 \mu \mathrm{l}$ of tissue section at $100 \mu \mathrm{m}$ from each end and one from the middle of the block) were stained with Mayer's haematoxylin and eosin. The sections were examined under a light microscope, with each section rated using a scoring system based on extent of observed damage: zero = no damage, indicating normal gill tissue (Fig. 4A); 1 = slightly damaged, with infiltration of hemocytes in connective tissue (Fig. 4B); 2 = severely damaged, with cilia detached from filament epithelial cells (Fig. 4C); 3 = diapedesis, passage of hemocytes through the damaged epithelial cells of the gill filament (Fig. 4D). Each biopsy specimen was examined by 2 pathologists (Y. Maeno \& T. Yurimoto). The gill damage on each clam was evaluated as the sum of the scores on 3 tissue sections.

\section{Statistical analysis}

The clearance-rate and phytopigment content values in digestive glands for each experimental treatment group were averaged for each 10 clams (total in 2 runs), and are expressed as mean \pm SD. All data sets were tested for normal distribution and homogeneity of variances prior to analysis. Because data sets for clearance rates showed normal distributions and homogeneity of variances, post hoc analysis was performed with Tukey's HSD test. Because the data sets for phytopigment content of digestive glands were not normally distributed, the nonparametric KruskalWallis test was used for that analysis. Subsequently, the effects of the treatments were also tested with the Mann-Whitney $U$-tests with a Bonferroni correction. 

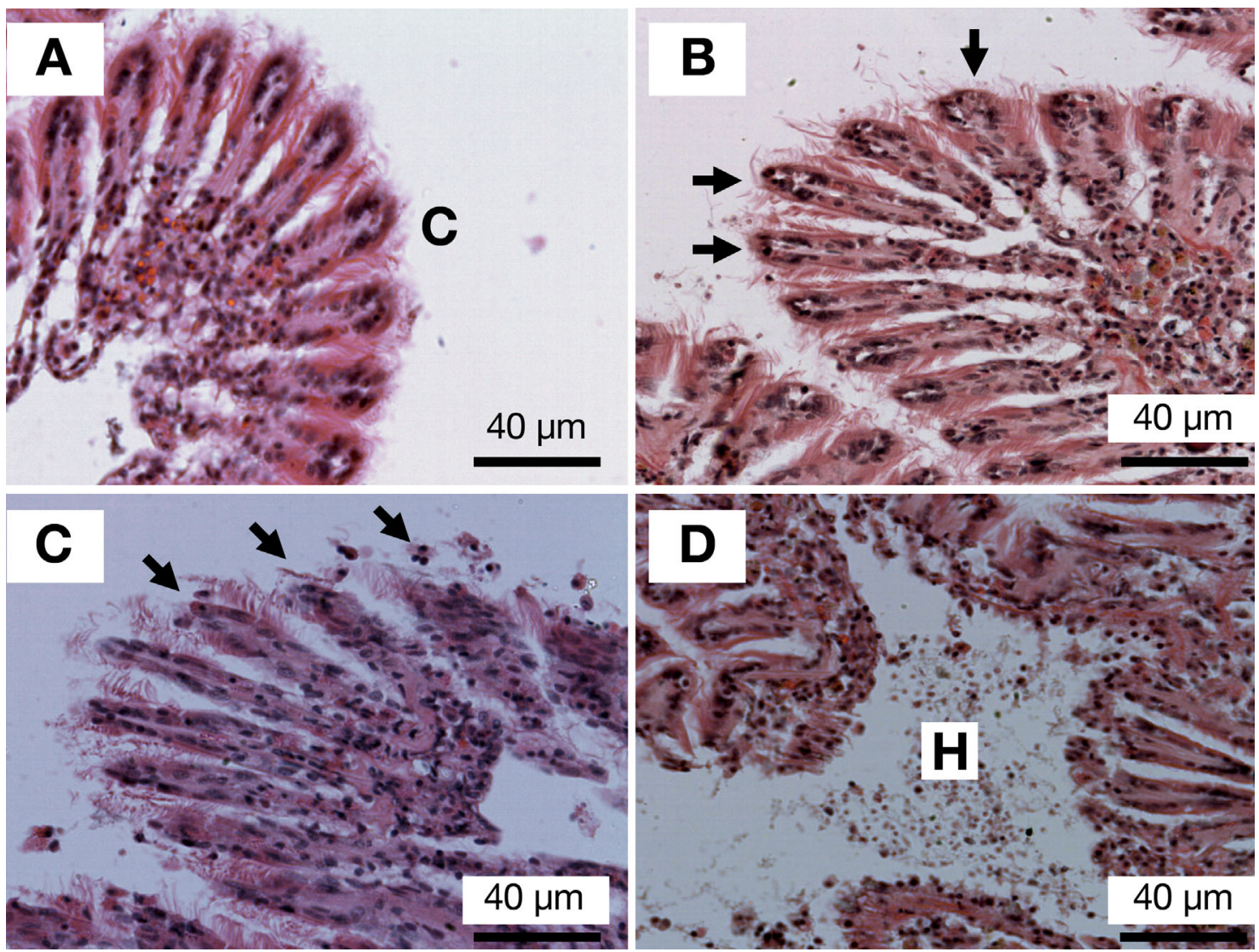

Fig. 4. Ruditapes philippinarum. Light-microscope images of gill tissue exposed to (A) normoxia and (B,C,D) anoxia with 30 mg $1^{-1} \mathrm{H}_{2} \mathrm{~S}$. (A) Normal gill tissue; (B) slightly damaged tissue, with infiltration of hemocytes in connective tissue; (C) severely damaged tissue, with cilia detached from epithelial cells of the filament; (D) diapedesis, i.e. passage of hemocytes through damaged epithelial cells of gill filament. Arrows point to exfoliated cilia from epithelial cells of filament. C: cilia; H: hemocyte

The histological scores for each experimental treatment group were the averages of scores for each of 6 clams (total in 2 runs), and are expressed as mean \pm SE. The Kruskal-Wallis test for significance was performed for the 4 groups (normoxia, anoxia only, 5 and $30 \mathrm{mg} \mathrm{l}^{-1}$ sulfidic anoxia). If a significant difference was seen, a Mann-Whitney $U$-test was performed between the normoxic group and the other groups. Statistical analyses were performed using SPSS 10.0 for Windows, with significance set at the $\mathrm{p}<0.05$ level.

\section{RESULTS}

\section{Anoxic incubation with and without $\mathrm{H}_{2} \mathrm{~S}$}

In the first experiment (Procedure 1), the mean initial concentrations of $\mathrm{H}_{2} \mathrm{~S}$ in each separable flask were $0.0 \pm 0.0 \mathrm{mg} \mathrm{l}^{-1}$ (mean $\pm \mathrm{SD}, \mathrm{n}=3$, normoxic conditions), $0.0 \pm 0.0 \mathrm{mg} \mathrm{l}^{-1}$ (anoxia without $\mathrm{H}_{2} \mathrm{~S}$ ), $5.1 \pm$
$0.3 \mathrm{mg} \mathrm{l}^{-1}\left(\mathrm{H}_{2} \mathrm{~S}\right.$ concentration of $\left.5 \mathrm{mg} \mathrm{l}^{-1}\right)$, and $27.7 \pm$ $2.5 \mathrm{mg} \mathrm{l}^{-1}\left(\mathrm{H}_{2} \mathrm{~S}\right.$ concentration of $\left.30 \mathrm{mg} \mathrm{l}^{-1}\right)$.

No mortality occurred in the clams exposed to anoxia with or without $\mathrm{H}_{2} \mathrm{~S}$ for $24 \mathrm{~h}$, even at the high $\mathrm{H}_{2} \mathrm{~S}$ concentration (30 $\mathrm{mg} \mathrm{l}^{-1}$ ). Although we observed clams reaction only a few times during the $24 \mathrm{~h}$ exposure period, all clams in $\mathrm{H}_{2} \mathrm{~S}$ solutions, whether at 5 or $30 \mathrm{mg} \mathrm{l}^{-1}$, extended their siphons into the water column. On the other hand, all clams under normoxia nearly closed their shells, and only slightly extended their siphons through the barely parted shell halves. Some clams under only anoxia extended their siphons at a length intermediate between those under normoxia and those under $\mathrm{H}_{2} \mathrm{~S}$ anoxic conditions. Other clams under anoxia alone reacted similarly to those under normoxia. Moreover, at the end of the $24 \mathrm{~h}$ exposure, all clams picked out of sulfidic water were unable to withdraw their siphons for some time. In contrast, the clams exposed to normoxia or to anoxia alone withdrew their siphons immediately, and closed their shell. 


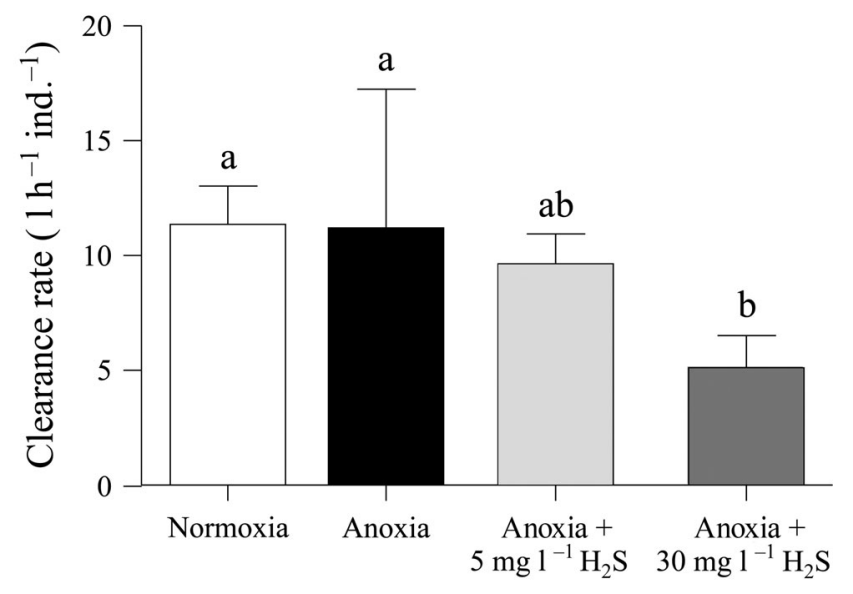

Treatment

Fig. 5. Ruditapes philippinarum. Clearance rates of clams exposed to various experimental conditions. Data represent the mean $\pm \mathrm{SD}(\mathrm{n}=10)$. Means with same letter are not significantly different ( $p>0.05$, Tukey's HSD test)

\section{Clearance rates}

As shown in Fig. 5, there was no significant difference in clearance rates between the clams treated with 5 or $30 \mathrm{mg} \mathrm{l}^{-1} \mathrm{H}_{2} \mathrm{~S}$ (Tukey's HSD test, $\mathrm{p}=0.189$ ), but the clearance rate for clams treated with $30 \mathrm{mg} \mathrm{l}^{-1}$ $\mathrm{H}_{2} \mathrm{~S}$ was significantly lower than those of clams exposed to normoxic $(\mathrm{p}=0.038)$ or only anoxic conditions ( $p=0.045$; Fig. 5).

At the end of the diatom exposure experiment, feces and pseudofeces were left at the bottom of each beaker. In the clams exposed either to normoxic conditions, anoxia only, or $5 \mathrm{mg} \mathrm{l}^{-1}$ sulfidic anoxia, feces had a sturdy and cylindrical appearance (Fig. 6A). Upon observation under a light microscope, the feces showed a dense composition (Fig. 6A). Pseudofeces of these clams had a fragile and amorphous appearance; the diatom cells were wrapped in mucus and each individual cell could be identified easily (Fig. 6B). In contrast, the clams exposed to $30 \mathrm{mg} \mathrm{l}^{-1}$ sulfidic anoxia ejected large blobs, distinct, both in form and degree of frailty, from the feces and pseudofeces of clams in the other treated groups; the blobs appeared to be sturdy and amorphous (Fig. 6C). The diatom cells found both in the large blobs and in the pseudofeces could be identified in each cell (Fig. 6C).

\section{Analysis of phytopigments in the digestive gland}

As shown in Fig. 7, phytopigment content of clams treated with $30 \mathrm{mg} \mathrm{l}^{-1}$ sulfidic anoxia was similar to that of food-deprived clams (initial control; Mann-
Whitney $U$-tests with Bonferroni correction, $\mathrm{p}=$ 0.448), but was significantly lower than that of the other experimental groups $(\mathrm{p}<0.01)$. In addition, the phytopigment content of clams exposed to only anoxic conditions or to $5 \mathrm{mg} \mathrm{l}^{-1}$ sulfidic anoxia was as high as that of clams under normoxic conditions ( $\mathrm{p}=$ 0.496 and $\mathrm{p}=0.650$, respectively; Fig. 7).

\section{Histological examination of gills}

No lesions were seen in clams exposed to normoxic conditions (Fig. 4A). In 1 and 2 individuals out of the groups of 6 clams exposed to either anoxia only or low sulfidic anoxia $\left(5 \mathrm{mg} \mathrm{l}^{-1}\right)$, respectively, slight lesions were observed in some areas of the gill tissue (Fig. 4B). No lesions were seen in any other clams of those experimental groups. Subsequently, no significant difference was observed between the histological score in clams treated under normoxic condition and the score in clams exposed to anoxia (MannWhitney $U$-test, $\mathrm{p}=0.699$ ) or low sulfidic anoxia ( $\mathrm{p}=$ 0.394 ; Table 1). In the clams exposed to anoxia with a high concentration of $\mathrm{H}_{2} \mathrm{~S}\left(30 \mathrm{mg} \mathrm{l}^{-1}\right.$ ), slight damage was observed in almost all of the gill tissue sections (Fig. 4B). Moreover, cilia detached from the epithelium of the gill filament (severe damage; Fig. 4C) and the passage of the epithelial cells of the gill filament (diapedesis; Fig. 4D) were observed only in the clams treated under high sulfidic anoxia $\left(30 \mathrm{mg} \mathrm{l}^{-1}\right)$. Among 6 clams, 2 were suffering severe damage and 3 diapedesis. Consequently, the histological score in the high-sulfidic anoxia group (30 $\left.\mathrm{mg} \mathrm{l}^{-1}\right)$ was significantly higher than in the normoxia group $(\mathrm{p}=0.015$; Table 1).

\section{DISCUSSION}

The tendency of some infaunal bivalves in sulfidic water to extend their siphons upward into the water column has been reported in both field (Jørgensen 1980) and laboratory studies (Rosenberg et al. 1991, Shumway et al. 1993, Oeschger \& Pedersen 1994, Laudien et al. 2002). Laudien et al. (2002) suggested that this extrusion of siphons into sulfidic water might be coupled with higher ventilation activity, but served mainly to monitor the water for better conditions. Oeschger \& Pedersen (1994) suggested that the siphons might contain a diffusive barrier against sulfide. We found that the manner of extrusion of siphons differed between the clams exposed to anoxia with and without sulfide. These observations suggest 


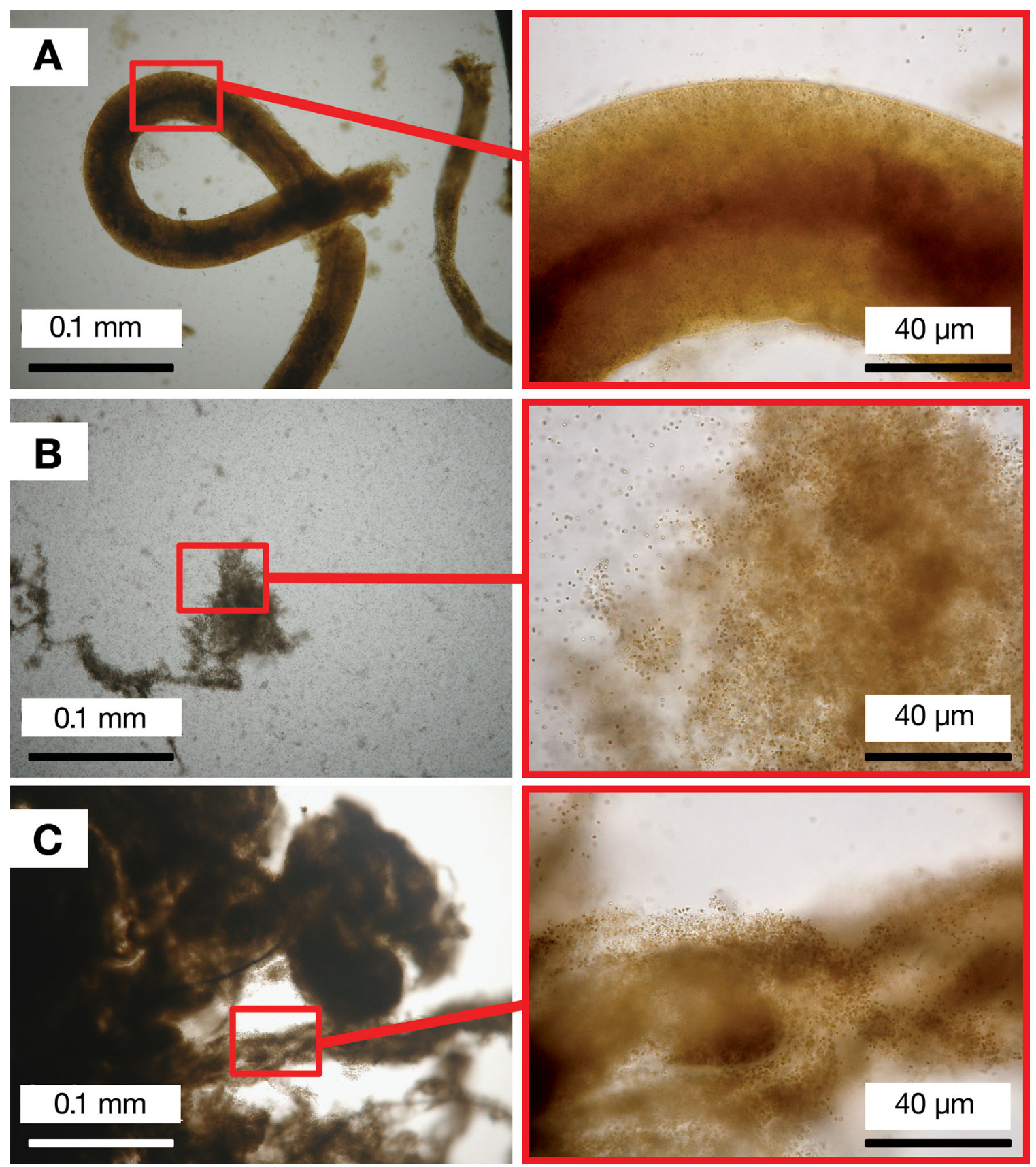

Fig. 6. Ruditapes philippinarum. Light-microscope images of fecal substances collected at the end of diatom exposure experiment. (A) Typical feces and (B) pseudofeces of clams exposed to normoxic conditions, anoxia only, or 5 mg $\mathrm{l}^{-1}$ sulfidic anoxia. (C) Typical material rejected by clams exposed to $30 \mathrm{mg} \mathrm{l}^{-1}$ sulfidic anoxia

that clams consciously extrude their siphons to obtain water of higher DO concentration. In the case of exposure to sulfidic anoxia, however, the siphons of clams involuntarily extended upward into the water column, from which we infer that $\mathrm{H}_{2} \mathrm{~S}$ may cause muscle relaxation. Therefore, clams (with extended siphons) removed from sulfidic water proved unable to withdraw their siphons immediately. Further studies are needed to understand why bivalves extrude their siphons in the presence of sulfide.

Marine invertebrates inhabiting $\mathrm{H}_{2} \mathrm{~S}$-rich marine sediments have acquired a variety of biochemical adaptations to detoxify this poisonous compound (Vismann 1991, Bagarinao 1992, Völkel \& Grieshaber 


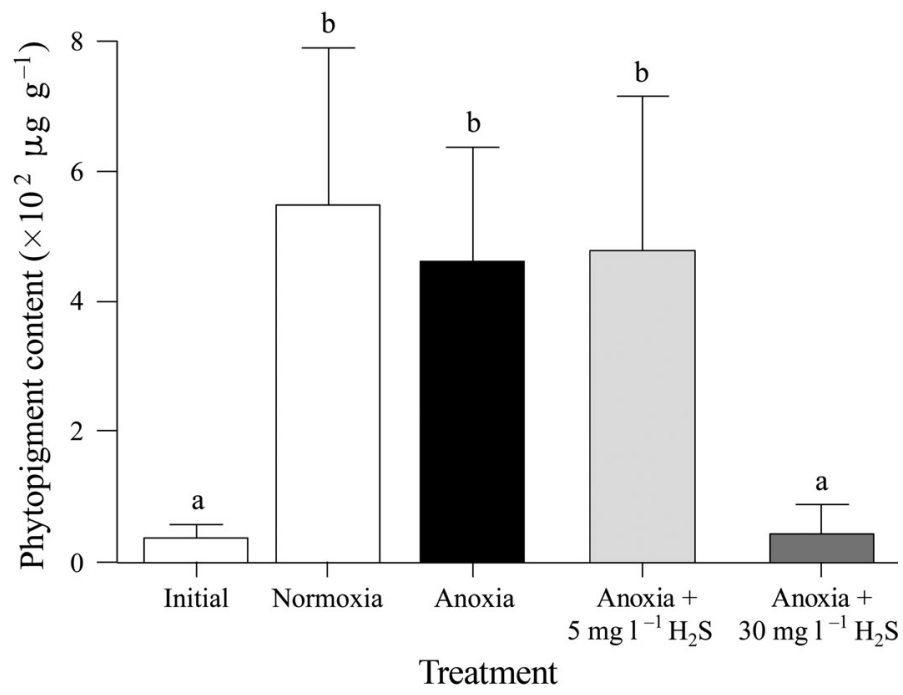

Fig. 7. Ruditapes philippinarum. Content of phytopigment (chl $a+$ phaeophytin) in digestive glands of clams exposed to various experimental conditions. Initial level is the concentration of phytopigment in digestive glands before exposure to diatoms. Data represent mean $\pm \mathrm{SD}(\mathrm{n}=10$, except for initial control $n=6$ ). Means with same letter are not significantly different ( $p>0.01$, Mann-Whitney $U$-test with Bonferroni correction)

Table 1. Comparison of histological lesion scores between the normoxic group and the other treatment groups. ${ }^{*} \mathrm{p}<0.05$

\begin{tabular}{|lcc|}
$\begin{array}{l}\text { Experimental } \\
\text { treatment group }\end{array}$ & $\begin{array}{c}\text { Histological score }(\mathrm{n}=6) \\
\text { Mean } \pm \mathrm{SE}\end{array}$ & $\mathrm{p}$ \\
\hline Normoxia & $0 \pm 0$ & \\
Anoxia without $\mathrm{H}_{2} \mathrm{~S}$ & $0.17 \pm 0.17$ & 0.699 \\
Anoxia with $5 \mathrm{mg} \mathrm{l}^{-1} \mathrm{H}_{2} \mathrm{~S}$ & $0.67 \pm 0.42$ & 0.394 \\
Anoxia with $30 \mathrm{mg} \mathrm{l}^{-1} \mathrm{H}_{2} \mathrm{~S}$ & $3.33 \pm 1.28$ & $0.015^{*}$ \\
\hline
\end{tabular}

1995, Grieshaber \& Völkel 1998). In marine bivalves, sulfide is metabolized to less toxic or non-toxic compounds through oxidizing cell tissue activity (Cary et al. 1989, O'Brien \& Vetter 1990). Thus, bivalves could tolerate $\mathrm{H}_{2} \mathrm{~S}$ if their body tissue were oxygenated. Because gill tissue is in intimate contact with ambient water, gill-tissue oxygen will be consumed for detoxification in $\mathrm{H}_{2} \mathrm{~S}$-containing water. Our observations clearly indicated that gill tissue is susceptible to the damaging effects of $\mathrm{H}_{2} \mathrm{~S}$.

Gills of bivalves act not only as respiratory organs but also as suspension-feeding organs. Suspended particles on the surface of bivalve gills are transferred to the mouth by ciliary movement. Gainey (2007) compiled previous results on particle capture and transport by gills and found that both the coordi- nated activity of cilia ( 3 groups of them) and gill geometry are absolutely essential to effective particle transport. Subtle changes in the structure of gill tissues can therefore lead to feeding dysfunction (Ward et al. 1993). In our study, clams exhibited difficulty in feeding when their gill tissues were damaged only at a high concentration of $\mathrm{H}_{2} \mathrm{~S}\left(30 \mathrm{mg} \mathrm{l}^{-1}\right.$; Fig. $4 \mathrm{C}, \mathrm{D})$. Because the exposure of clams to $\mathrm{H}_{2} \mathrm{~S}$ in our study was effected by a batch-culture technique, the initial concentration of $\mathrm{H}_{2} \mathrm{~S}$ likely decreased gradually during the $24 \mathrm{~h}$ exposure period. This may have been due, e.g. to the clams' detoxification of $\mathrm{H}_{2} \mathrm{~S}$. However, we did not analyze the time-dependent decline in the concentration of $\mathrm{H}_{2} \mathrm{~S}$. If the low concentration of $\mathrm{H}_{2} \mathrm{~S}\left(5 \mathrm{mg} \mathrm{l}^{-1}\right)$ had been maintained throughout the experimental period, the gill tissue might have been damaged more seriously than our observations indicate, and the clearance rate would likely have declined with the degree of gill damage. Alternatively, serious damage to gill tissue may be produced by the accumulation of slight injuries due to periodic exposure to low concentrations of $\mathrm{H}_{2} \mathrm{~S}$. In either case, further studies should undertake to examine the impact of low concentrations of $\mathrm{H}_{2} \mathrm{~S}$ on the physiological processes and activities of bivalves, including respiration and feeding.

Mucus plays a key role in all aspects of particle processing on the gill surface (Beninger et al. 1991, Beninger et al. 1993, 1997a,b, Beninger \& Le Pennec 1993, Beninger \& Dufour 1996, Beninger \& St-Jean 1997a,b, Wotton 2004). Mucus consists of polysaccharide units with associated protein components (mucopolysaccharides; MPS). The MPS can be divided into 3 classes according to degree of acidity and viscosity: (1) acid MPS (AMPS) and acid-dominant MPS (ADMPS), both exhibiting high viscosity; (2) neutral MPS (NMPS), exhibiting low viscosity; and (3) mixed MPS (MMPS), containing roughly equal proportions of AMPS and NMPS, and exhibiting relatively low viscosity (Beninger \& St-Jean 1997b). In addition, these various classes of MPS play particular roles in gill-surface particle processing. High-viscosity AMPS and ADMPS act to reject pseudofeces; lowerviscosity MMPS is involved in transport of particles destined for ingestion; and low-viscosity NMPS dilutes AMPS and ADMPS to reduce their viscosity (Beninger and St-Jean 1997b). The properties and components of mucus are therefore important for the feeding activity of bivalves. Thus clams exposed to a high concentration of $\mathrm{H}_{2} \mathrm{~S}\left(30 \mathrm{mg} \mathrm{l}^{-1}\right.$ ) may secrete mucus with altered components resulting from direct damage to gill tissue, and this in turn may disrupt particulate transport on the gill surface. Although we 
did not examine the alteration of gill mucus components, this hypothesis is supported by the observation that clams exposed to high sulfidic anoxia ejected fecal substances that were different from normal feces or pseudofeces (Fig. 6).

Among clams exposed to $30 \mathrm{mg} \mathrm{l}^{-1}$ sulfidic anoxia, the diatom cell concentration decreased (through filtration for $4 \mathrm{~h}$ ) from $28257 \pm 469$ cells ml$^{-1}$ (mean \pm $\mathrm{SE}, \mathrm{n}=10$ ) to $14948 \pm 2964 \mathrm{cells} \mathrm{ml}^{-1}$. However, the amount of phytopigment in the digestive glands of these clams $\left(41.7 \mathrm{\mu g} \mathrm{g}^{-1}\right)$ was similar to that in fooddeprived clams (37.7 $\mu \mathrm{g} \mathrm{g}^{-1}, \mathrm{p}=0.448$; Fig. 7). Thus diatoms that disappeared from the water were not ingested, but were ejected as sturdy and amorphous large blobs. This finding suggests that clams damaged by $\mathrm{H}_{2} \mathrm{~S}$ would be more likely to die of malnutrition.

This is the first study we know of to elucidate the physiological sequelae and tissue damage of bivalves caused by exposure to $\mathrm{H}_{2} \mathrm{~S}$. Our findings indicate that the Manila clam Ruditapes philippinarum is not killed directly by short-term exposure to $\mathrm{H}_{2} \mathrm{~S}$, but that the gill tissue is damaged by exposure to $\mathrm{H}_{2} \mathrm{~S}$, and the clams are therefore incapable of feeding normally. Although the environment may return to optimal conditions, such clams would starve or be gradually debilitated as a result of the sulfide-caused damage to their gills. Consequently, debilitated clams would be more susceptible to disease and death. These impacts of $\mathrm{H}_{2} \mathrm{~S}$ may be related to the mortality of bivalves in the field.

Acknowledgements. The authors thank Y. Kotani and M. Aritaki for helping to revise the manuscript and for making useful suggestions.

\section{LITERATURE CITED}

Bagarinao T (1992) Sulfide as an environmental factor and toxicant: tolerance and adaptations in aquatic organisms. Aquat Toxicol 24:21-62

Beninger PG, Dufour SC (1996) Mucocyte distribution and relationship to particle transport on the pseudolamellibranch gill of Crassostrea virginica (Bivalvia: Ostreidae). Mar Ecol Prog Ser 137:133-138

- Beninger PG, Le Pennec M (1993) Histochemistry of the bucco-oesophageal glands of Mytilus edulis: the importance of mucus in ingestion. J Mar Biol Assoc UK 73: 237-240

> Beninger PG, St-Jean SD (1997a) Particle processing on the labial palps of Mytilus edulis and Placopecten magellanicus (Mollusca: Bivalvia). Mar Ecol Prog Ser 147:117-127

$>$ Beninger PG, St-Jean SD (1997b) The role of mucus in particle processing by suspension-feeding marine bivalves: unifying principles. Mar Biol 129:389-397
Beninger PG, Le Pennec M, Donval A (1991) Mode of particle ingestion in five species of suspension-feeding bivalve molluscs. Mar Biol 108:255-261

Beninger PG, St-Jean S, Poussart Y, Ward JE (1993) Gill function and mucocyte distribution in Placopecten magellanicus and Mytilus edulis (Mollusca: Bivalvia): the role of mucus in particle transport. Mar Ecol Prog Ser 98:275-282

Beninger PG, Dufour SC, Bourque J (1997a) Particle processing mechanisms of the eulamellibranch bivalves Spisula solidissima and Mya arenaria. Mar Ecol Prog Ser 150: 157-169

Beninger PG, Lynn JW, Dietz TH, Silverman H (1997b) Mucociliary transport in living tissue: the two-layer model confirmed in the mussel Mytilus edulis L. Biol Bull 193:4-7

- Cary SC, Vetter RD, Felbeck H (1989) Habitat characterization and nutritional strategies of the endosymbiont-bearing bivalve Lucinoma aequizonata. Mar Ecol Prog Ser 55: 31-45

Chew KK (1989) Manila clam biology and fishery development in western North America. In: Manzi JJ, Castagna $\mathrm{M}$ (eds) Clam mariculture in North America. Elsevier, Amsterdam, p 243-261

Cline JD (1969) Spectrophotometric determination of hydrogen sulfide in natural waters. Limnnol Oceanogr 14: 454-458

Coughlan J (1969) The estimation of filtering rate from the clearance of suspensions. Mar Biol 2:356-358

Diaz RJ, Rosenberg R (1995) Marine benthic hypoxia: a review of its ecological effects and the behavioural responses of benthic macrofauna. Oceanogr Mar Biol Annu Rev 33:245-303

Gainey LF Jr (2007) Seasonal control of particle clearance by isolated gills from the clam Mercenaria mercenaria. J Exp Biol 210: 2518-2525

Grieshaber MK, Völkel S (1998) Animal adaptations for tolerance and exploitation of poisonous sulfide. Annu Rev Physiol 60:33-53

Hagita K (1985) The effects of dysoxic and hydrogen sulfide water on the mortality of Manila clam. Suisanzoshoku 33: 67-71 (in Japanese)

Higano J (2005) Influence of environmental factors as oxygen deficiency, hydrogen sulfide and suspended mud on the survival and growth of Manila clam. Bull Fish Res Agen Suppl. 3:27-33 (in Japanese with English abstract)

Jahn A, Theede H (1997) Different degrees of tolerance to hydrogen sulphide in populations of Macoma balthica (Bivalvia, Tellinidae). Mar Ecol Prog Ser 154:185-196

Jahn A, Janas U, Theede H, Szaniawska A (1997) Significance of body size in sulphide detoxification in the Baltic clam Macoma balthica (Bivalvia, Tellinidae) in the Gulf of Gdansk. Mar Ecol Prog Ser 154:175-183

$>$ Jørgensen BB (1980) Seasonal oxygen depletion in the bottom waters of a Danish fjord and its effect on the benthic community. Oikos 34:68-76

- Laudien J, Schiedek D, Brey T, Pörtner HO, Arntz WE (2002) Survivorship of juvenile surf clams Donax serra (Bivalvia, Donacidae) exposed to severe hypoxia and hydrogen sulphide. J Exp Mar Biol Ecol 271:9-23

> Le Moullac G, Cheize M, Gastineau O, Daniel JY and others (2008) Ecophysiological and metabolic adaptations to sulphide exposure of the oyster Crassostrea gigas. J Shellfish Res 27:355-363

Nagasoe S, Suzuki K, Yurimoto T, Fuseya R and others (2011) Clearance effects of the Pacific oyster Crassostrea 
gigas on the fish-killing algae Chattonella marina and Chattonella antiqua. Aquat Biol 11:201-211

Nakamura M, Shinagawa A, Toda K, Nakao S (1997) Tolerance of 4 bivalves from lakes Shinji and Nakaumi to environmental factors. Suisanzoshoku 45:179-185 (in Japanese with English abstract)

Numaguchi K (2001) Phyto-pigments in the digestive diverticula of juvenile Japanese pearl oyster, Pinctada fucata martensii, as indicator of algal diets feeding. Suisanzoshoku 49:317-322 (in Japanese with English abstract)

O'Brien J, Vetter RD (1990) Production of thiosulphate during sulphide oxidation by mitochondria of the symbiontcontaining bivalve Solemya reidi. J Exp Biol 149:133-148

Oeschger R, Pedersen TF (1994) Influence of anoxia and hydrogen sulphide on the energy metabolism of Scrobicularia plana (da Costa) (Bivalvia). J Exp Mar Biol Ecol 184:255-268

Ostlund HG, Alexander J (1963) Oxidation rate of sulfide in sea water, a preliminary study. J Geophys Res 68: 3995-3997

Rosenberg R, Hellman B, Johansson B (1991) Hypoxic tolerance of marine benthic fauna. Mar Ecol Prog Ser 79: $127-131$

Sakai S, Nakaya M, Takayasu K (2004) Hydrogen sulfide distribution in bottom and pore waters during an anoxic period in Lake Nakaumi, Japan. Laguna 11:65-68

Shumway SE, Scott TM, Shick JM (1993) The effects of

Editorial responsibility: Riccardo Cattaneo-Vietti,

Genova, Italy anoxia and hydrogen sulphide on survival, activity and metabolic rate in the coot clam, Mulinia lateralis (Say). J Exp Mar Biol Ecol 71:135-146

Smith L, Kruszyna H, Smith RP (1977) The effect of methemoglobin on the inhibition of cytochrome $c$ oxidase by cyanide, sulfide or azide. Biochem Pharmacol 26: 2247-2250

Strickland JDH, Parsons TR (1968) A practical handbook of seawater analysis. Fish Res Bd Canada Bull 167:185-194

> Vaquer-Sunyer R, Duarte CM (2010) Sulfide exposure accelerates hypoxia-driven mortality. Limnol Oceanogr 55: 1075-1082

Vismann B (1991) Sulfide tolerance: physiological mechanisms and ecological implications. Ophelia 34:1-27

Völkel S, Grieshaber MK (1995) Sulfide tolerance in marine invertebrates. In: Heisler N (ed) Mechanisms of systemic regulation: acid-base regulation, ion transfer and metabolism (Advances in comparative and environmental physiology, Vol 22). Springer-Verlag, Berlin, p 233-257

> Ward JE, MacDonald BA, Thompson RJ (1993) Mechanisms of suspension feeding in bivalves: resolution of current controversies by means of endoscopy. Limnol Oceanogr 38:265-272

Wotton RS (2004) The ubiquity and many roles of exopolymers (EPS) in aquatic systems. Sci Mar 68:13-21

Yatsuka T (1953) Reduced layer of bottom sediment and Manila clam. Suisanzoshoku 1:45-47 (in Japanese)

Submitted: November 15, 2010; Accepted: August 29, 2011 Proofs received from author(s): November 2, 2011 